\title{
FACTORS INFLUENCING THE FOREIGN DIRECT INVESTMENT INFLOW IN THE CZECH REPUBLIC
}

\author{
[Faktory ovlivňující příliv př́ímých zahraničních investic do České republiky]
}

\author{
Veronika Linhartová ${ }^{1}$ \\ ${ }^{1}$ Univerzita Pardubice, Fakulta ekonomicko-správní, Studentská 95, 53210 Pardubice \\ Email:veronika.linhartova@upce.cz
}

\begin{abstract}
Foreign direct investment opens new work opportunities, positively influences workforce productivity, introduces the latest findings and technological know-how and positively influences the balance of payments. The aim of the paper is to identify, based on the available literature, the possible factors influencing the inflow of foreign direct investment into the country and, using statistical methods, to identify specific factors influencing the inflow of foreign direct investment into the Czech Republic during the period from 1998 to 2015. Using the multiple regression model, Science and research expenditures, GDP, corporate tax income and the Corruption Perceptions Index have emerged as significant factors. While spending on science and research or the GDP seem to have a positive effect on FDI, corporate tax and Corruption Perceptions Index appear to be negative in the results in the Czech Republic and the analyzed period.
\end{abstract}

Keywords: foreign direct investment, foreign direct investment inflow, foreign direct investment determinants, multiple regression analysis.

JEL Classification: D73, E2, F21

Doručeno redakci: 13.11.2017; Recenzováno: 23.11.2017; 1.12.2017; Schváleno k publikování: 14.3.2018

\section{Introduction}

The issue of foreign direct investment is becoming an increasingly discussed topic in terms of possibilities of influencing their volume and their benefits for the national economy.

Foreign direct investment can be defined as "an investment in another country that serves to obtain a share of common stock and decision-making powers of at least $10 \%$ or a share giving the foreign investor the decision-making power" (Liebscher 2007). Host countries have an interest in foreign investment mainly because of their positive effects. Professional literature states that new investments can influence the labor market, increase competitiveness and complement the lack of domestic capital. Foreign direct investment can also bring new management practices, know-how, innovation or interconnection of national economies. Investments may also have negative impacts, such as crowding out domestic businesses or inequality of investment inflows into different industries. It is therefore necessary for the host country to consider the possible consequences of the inflow of foreign direct investment.

Each country has certain factors that are important for investor decision-making. Many of these factors can influence the host economy and encourage interest from foreign investors. Some factors such as the position of the state, on the other hand, cannot influence the host economy (Benáček, Víšek 2000; Valach 1996). Investors generally prefer countries that are attractive for some reason. A unified definition of factors that are decisive for investors is quite difficult, however, countries wishing to support the flow of foreign investment use variety of tools to attract investors, including host country promotion, investment incentives, or aftercare services (Dvořáček 2005; Viturka 2000). 
In the Czech Republic, there was a turning point in 1995, when a new Foreign Exchange Act No. 219/1995 was introduced, allowing the convertibility of the Czech currency and the free movement of capital. Another important milestone was Government Resolution No. 298 in 1998, which launched investment support through investment incentives. At that time, the government's approach had also changed, which was aimed at improving and clarifying the legislative environment, improving support for small and medium-sized enterprises and supporting research and development. These changes led to an increase in the number of foreign partners in the Czech Republic and significantly affected the current situation in foreign direct investment.

The aim of the paper is to identify, on the basis of the research carried-out, the possible factors influencing the inflow of foreign direct investment into the country and, using statistical methods, to identify specific factors influencing the inflow of foreign direct investment into the Czech Republic.

\section{Theoretical background}

Professional literature focusing on the foreign direct investment (FDI is used in the following text) defines several factors, according to which foreign investors usually decide.

Common factors include, for example, political stability, the quality of legislative regulations, economic growth intensity, interest rate levels, openness of the economy, tax burden or risks related to inflation, movement of rates, economic cycles and interest rates. Business factors are proximity to customers, the availability of raw material resources, or the presence of companies of the same business orientation (Benáček, Víšek 2000; Valach 1996; Viturka 2000). Factors at regional and local level are considered to be very important for the FDI acquisition. These include a high-quality offer of development areas, commercially exploitable building sites and the attractiveness of the region, city or municipality. Regional marketing provides information to end recipients about offers of locations suitable to support economic activities or to support the implementation of development projects co-financed by public funds. An important prerequisite for the successful realization of marketing activity is the correct marketing strategy based on the national development strategy. The regional and local factors include the area's technical infrastructure, the quality of the transport connection of the region, the size of the settlement center and the technical and user characteristics of the buildings (Dvoř́čček 2005; Viturka 2000)

Factors influencing foreign capital inflows have also been addressed in a number of empirical studies. The authors Bénassy-Quéré, Coupet, and Mayer (2007) analyzed the impact of factors on FDI in OECD countries in 1985-2000. They investigated the impact of various factors on FDI, but also whether these factors affect the FDI positively or negatively. Their results have shown that common factors such as language, the gross domestic product (just GDP is used in the following text), labor productivity, consumer productivity, or legislation on investor protection are among the factors that have a positive impact on the flow of investment in these countries. Interesting was the discovery and influence of corruption. They have shown that countries with high levels of corruption have up to 7.9 times the influx of the FDI. As negative factors that have a major impact on discouraging investors, the authors have described employment protection and a weak concentration of capital. Employers are understood to mean employment law, which regulates working hours and the conditions of remuneration of workers. 
The above-mentioned authors were followed by Blonigen and Piger (2014), who identified a common language and trade openness as a significant factor. Their results assume that language affinity will affect the FDI inflows in up to $85 \%$ of the countries surveyed. Trade openness, i.e the existence of a customs union and free trade agreements, affects the FDI in up to $90 \%$ of cases.

The afore mentioned studies by Bénassy-Quéré, Coupet and Mayer does not agree with authors Demekas et al. (2007) who claim that corruption and tax holidays have no impact on the FDI. Their work contains data from 1995-2003 from individually selected countries including the Czech Republic. Previous studies have provided evidence to confirm that if the level of income of the country increases, the significance of the influence of other FDI factors decreases and the factors become crucial in a domestic market and the business environment. Unlike other studies, they also assesed an environmental factor which had been shown to influence the influx of the FDI.

Holland and Pain (1998) paid attention to the inflow of the FDI into the transforming economies. They assumed that the FDI is necessary for this states to "kick-start" their economy. Hence, they studied 8 states including the Czech Republic to verify this. The results of the study have shown that the possibility of realizing privatization, proximity to Western and more developed countries, and emerging trade relations between states have a significant impact on the growth of economies. Another finding was the independence of investment in wage costs and the capabilities of workers. The authors claim they have only a marginal role in the final decision of the investor. The most crucial factors were geographical proximity, trade agreements and the opening of accession negotiations with the European Union.

Carstensen and Toubal (2004) examined the FDI determinants in Central and Eastern European countries. In recent years, there has been a significant increase in investment in Central Europe (Czech Republic, Hungary, Poland, Slovakia), while Eastern European countries (Bulgaria and Romania) have lagged behind. The classic factors mentioned in previous studies added market potential, corporate costs, business environment, investment incentives, corporate tax rates. As part of their analysis, the authors of the study divided the time series into short and long-term ones. The result of the study was that if the market potential of the host country increased by an average of $1 \%$, an increase of the FDI could be expected by $\$ 166$ million in the first year. In the long run, it is up to $\$ 246$ million. Another factor the authors dealt with was wage costs. The fall in these costs will increase the FDI inflow in the first year by $\$ 25$ million and in the long run by up to $\$ 37$ million. Additional significant factors identified to affect the FDI were market environment, low labor costs, POs taxes and related subsidies. Likewise, a skilled workforce is crucial to the introduction of innovative manufacturing technologies. Another corporate FDI determinant is a corporate tax, with a $1 \%$ decrease in the first year averaging an inflow of $\$ 2.5$ million. This factor, according to the authors mentioned, is not one of the most important factors, as well as the quality of workforce and the innovation of technologies.

Authors Bevan and Estrin (2004) investigated the FDI inflows in 1994-2000 in selected host countries, including the Czech Republic. In the empirical study, they used as variables the GDP, inflation, exchange rate risk, institutional development indicators, and country risk for potential investor ratings. The authors of the study considered a significant factor for the inflow of the FDI, especially the GDP of the host country. They also confirmed the negative relationship between the FDI and wage costs, so the inflow of investment was in areas with lower labor cost per unit. The market risk was quite a surprising revelation from the analysis, as it was shown that the FDI flows are not affected by this factor. The study also dealt with 
the impact of joining the European Union on the FDI, with the authors concluding that the flow of investment will be compounded by the mere announcement by the European Union of a country's accession.

Biswas (2002) described the respecting of property rights in the country as one of the most important factors. This is very important for investors because they prefer investing in an environment that guarantees greater certainty that their capital will be maintained. An important factor is also democracy that protects the individual property rights. It also allows effective transmission of government policy information, which investors welcome.

There are differences in the evaluation of the authors mentioned in the area of identification of FDI inflow determinants in the host economy which can be caused by a considerable difference of the surveyed sample of countries, the different methodology of the survey and the time when studies were conducted.

\section{Methods}

To fulfill the objective of the research, a multiple regression analysis method is used, which makes it possible to assess the influence of selected determinants on the FDI inflow into the Czech Republic. It also makes it possible to determine the interdependence or independence of the chosen factors.

The least squares (OLS) estimates are used in the analysis. Multiple regression analysis seeks values of the dependent variable from a linear combination of values of two or more independent variables. The formula can be expressed as follows:

$$
Y=\beta_{0}+\beta_{1} X_{1}+\beta_{2} X_{2}+\beta_{3} X_{3}+\ldots
$$

where:

$\mathrm{Y}$ - dependent variable,

$\beta 0$ - constant,

$\beta 1, \beta 2, \beta 3$ - regression coefficients,

$\mathrm{X} 1, \mathrm{X} 2, \mathrm{X} 3$ - values of an independent variable.

Multiple regression analysis can explain the variance of the dependent variable $\mathrm{Y}$, determine the effect of each independent variable $\mathrm{X}$ on the dependent variable $\mathrm{Y}$ and predict the values for individual cases (Hebák et al., 2005)

To use the multiple regression analysis, data must meet a number of assumptions that ensure unbiased results of regression analysis. These assumptions include the normal distribution of variables, the occurrence of homoscedasticity, the absence of multicollinearity, the variables must be metric, and the data must not be outlying values (Víšek, 1998). All assumptions of multiple regressions were verified for the purposes of the analysis.

All modeling and testing of variables was also carried out using Gretl software, testing with a $5 \%$ level of significance.

\section{Analysis of Foreign Direct Investment Determinants in the Czech Republic}

The specific localization factors were selected for the regression analysis based on the literature and foreign empirical studies mentioned in the second chapter of the paper. A set of test variables is available in the 1998-2015-time series. This period was selected due to another foreign direct investment record methodology prior to 1998, which could lead to 
distorted results. The used variables were selected based on the literature research made in the chapter 1. The analyzed variables were obtained from the statistics of the Czech National Bank, the Czech Statistical Office, CzechInvest and Transparency International.

The following variables were chosen for the specific localization factors:

FDI inflow $=f$ (general unemployment rate, the GDP, the GDP per capita, minimum wage, Corruption Perceptions Index, corporate tax rate, rating, CZE / EUR nominal exchange rate, science and research expenditure, Index of Economic Freedom, investment incentives).

The multiple regression model for identifying the FDI determinants in the Czech Republic can thus be expressed according to the formula (1) in the form:

$$
\begin{aligned}
& \text { FDI } I_{t} \text { inflow }=\beta_{0}+\beta_{1} U R_{t-1}+\beta_{2} G D P_{t-1}+\beta_{3} G D P / c_{t-1}+\beta_{4} M W_{t-1}+\beta_{5} C P I_{t-1}+\beta_{6} T A X_{t-1}+\beta_{7} R G_{t-} \\
& 1+\beta_{8} N E x R_{t-1}+\beta_{9} S R_{t-1}+\beta_{10} I E F_{t-1}+\beta_{11} I I_{t-1}
\end{aligned}
$$

where are:

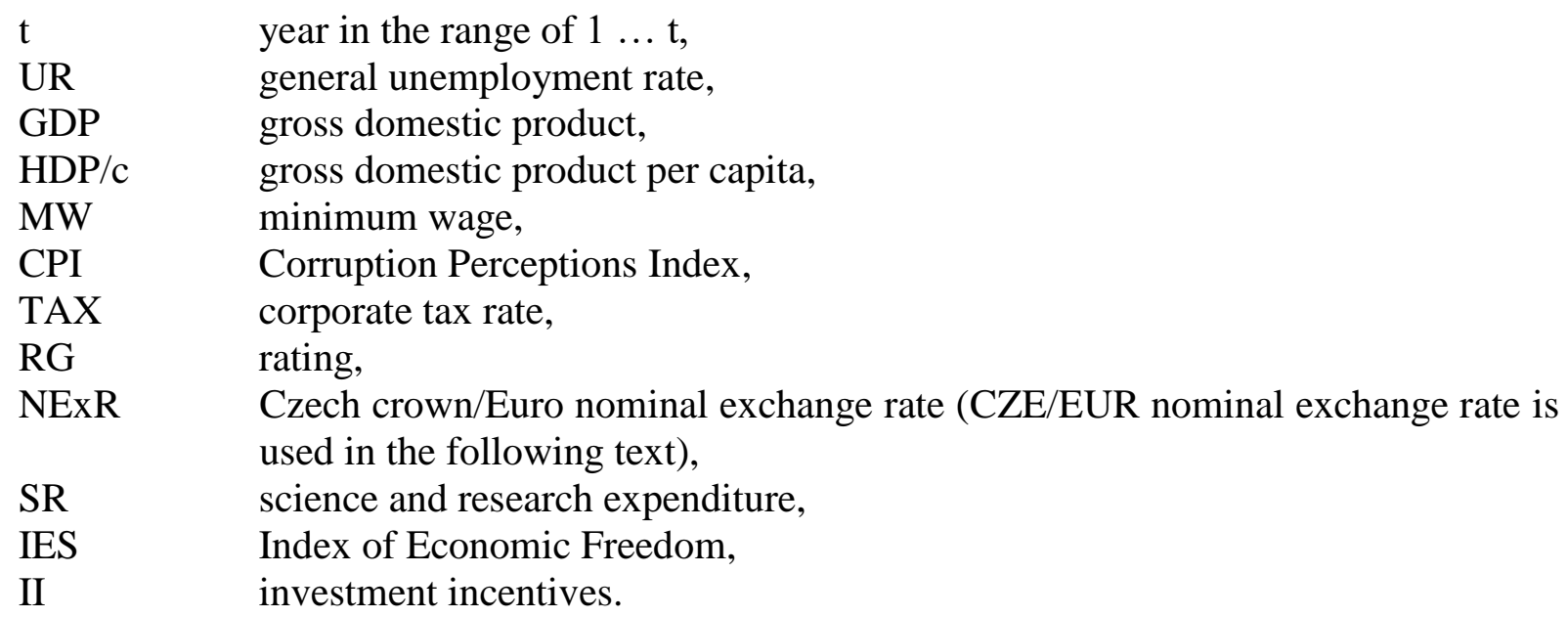

For independent variables, a one-year delay will be taken into account. The reason for this delay could be seen in studies by a number of authors (Blonigen, Piger 2014, Carstensen, Toubal 2004, CzechInvest 2015, Holland, Pain 1998) dealing with FDI issues. According to these authors, investors are reacting to the changing situation in the host economy with a delay, as they are waiting to confirm latest information even in the next period. Another reason is also the lengthy registration of starting entrepreneurs.

Prior to using multiple regression analysis, multi-collinearity must be verified. This is due to the interaction of independent variables. From Table 1, this situation occurs among just a few variables. For this reason, some independent variables must be excluded from multiple regression analysis. Two factors were excluded from the test sample based on the largest number of multi-collinears with independent factors. Most dependencies have been demonstrated on the GDP per capita which has been shown to have multi-collinearity with 6 independent factors. Another variable that will be discarded for the next analysis is the CZE / EUR exchange rate, as the dependence on 5 indicators has been demonstrated. 
Table 1: Multicolinearity test

\begin{tabular}{|c|r|r|r|r|r|r|r|r|r|r|c|}
\hline UR & GDP/c & GDP & \multicolumn{1}{l|}{ MW } & \multicolumn{1}{l|}{ SR } & \multicolumn{1}{c|}{ II } & CPI & TAX & NExR & IEF & RG & \\
\hline 1 & $-0,28$ & $-0,27$ & $-0,12$ & $-0,24$ & $-0,25$ & $-0,69$ & 0,17 & 0,20 & $-0,30$ & 0,23 & UR \\
\hline & 1 & 0,99 & 0,96 & 0,92 & 0,99 & 0,67 & $-0,97$ & $-0,93$ & 0,45 & $-0,81$ & GDP/c \\
\hline & & 1 & 0,97 & 0,91 & 0,99 & 0,66 & $-0,97$ & $-0,93$ & 0,42 & $-0,80$ & GDP \\
\hline & & & 1 & 0,84 & 0,96 & 0,49 & $-0,95$ & $-0,93$ & 0,25 & $-0,68$ & MW \\
\hline & & & & 1 & 0,93 & 0,66 & $-0,88$ & $-0,77$ & 0,66 & $-0,94$ & SR \\
\hline & & & & & 1 & 0,63 & $-0,98$ & $-0,93$ & 0,47 & $-0,83$ & II \\
\hline & & & & & & 1 & $-0,55$ & $-0,47$ & 0,45 & $-0,57$ & CPI \\
\hline & & & & & & & 1 & 0,94 & $-0,42$ & 0,78 & TAX \\
\hline & & & & & & & & 1 & $-0,24$ & 0,70 & NExR \\
\hline & & & & & & & & & & $-0,74$ & IEF \\
\hline & & & & & & & & & & & RG \\
\hline
\end{tabular}

Source: Own processing based on CNB (2016, 2017), CSO (2016, 2017), CzechInvest (2015), TI (2016)

Due to the multi-collinearity, GDP per capita and CZE / EUR exchange rate can not be included in a multiple regression model. Thus, the number of variables from the original 11 was reduced to 9 variables entering to the regression model.

After excluding the above factors, the regression model can be written according to the formula (1):

$F D I_{t}$ inflow $=\beta_{0}+\beta_{1} U R_{t-1}+\beta_{2} G D P_{t-1}+\beta_{3} M W_{t-1}+\beta_{4} C P I_{t-1}+\beta_{5} T A X_{t-1}+\beta_{6} R G_{t-1}+\beta_{7} S R_{t-1}+$ $\beta_{8} I E F_{t-1}+\beta_{9} I_{t-1}$

The next step is modeling of determinants that influence the inflow of the FDI into the Czech Republic using the regression analysis mentioned above. The aim is to find a solution that will appear to be the most appropriate for the choice of model using the adjusted determinant coefficient (R2adj), which is considered a comparative quality variable.

A better model can be identified from the value of the information criteria, while the lower the value of the information criteria, the better the model. In order to test the best selected regression analysis model, information criteria were used, including the Schwarz information criterion (BIC), the AIK and the Hannan-Quinn information criterion (HIC) (Bill, Němec, Pospiš, 2009).

For multiple regression analysis, the following hypotheses apply:

H0: parameters are insignificant,

H1: parameters are significant.

Rejection the zero hypothesis will occur when the p-value is lower than alpha (ie 0.05). For this reason, the results of the original model shown in Table 2 are unsatisfactory, and remodeling has been used to remove factors with the highest p-value. The resulting model after adjustments only includes significant variables that meet the assumptions to reject the zero hypotheses. The resulting model therefore contains only statistically significant variables.

Table 2 contains calculations for both, the original regression model and the new model including only significant variables that meet the assumptions to reject the zero hypotheses. 
Table 2: Multiple regression analysis

\begin{tabular}{|c|c|c|c|c|}
\hline & \multicolumn{2}{|c|}{ Original model } & \multicolumn{2}{|c|}{ Resulting model } \\
\hline & Coefficient B & p-value & Coefficient B & p-value \\
\hline Const & 906,8620 & 0,6400 & 1800,2500 & $0,0396 * *$ \\
\hline UR & $-32,5781$ & 0,2525 & & \\
\hline GDP & 0,6516 & 0,2512 & 0,4315 & 0,0096 *** \\
\hline MW & $-0,0652$ & 0,5759 & & \\
\hline CPI & $-20,7404$ & 0,2214 & $-15,0402$ & $0,0507 *$ \\
\hline TAX & $-30,3660$ & 0,1510 & $-40,5311$ & $0,0123 * *$ \\
\hline RG & 20,1198 & 0,8210 & & \\
\hline SR & 10,6922 & 0,2110 & 12,0960 & $8,90 \mathrm{e}^{-5 * * *}$ \\
\hline IEF & $-1,7700$ & 0,9150 & & \\
\hline II & 0,0009 & 0,8007 & & \\
\hline $\mathbf{R}^{2}$ & \multicolumn{2}{|c|}{0,9934} & \multicolumn{2}{|c|}{0,9947} \\
\hline $\mathbf{R}_{\text {adj. }}$ & \multicolumn{2}{|c|}{0,9902} & \multicolumn{2}{|c|}{0,9925} \\
\hline p-value (F) & \multicolumn{2}{|c|}{0,0008} & \multicolumn{2}{|c|}{0,00001} \\
\hline $\mathrm{AIC}$ & \multicolumn{2}{|c|}{213,8221} & \multicolumn{2}{|c|}{208,1861} \\
\hline BIC & \multicolumn{2}{|c|}{222,7258} & \multicolumn{2}{|c|}{213,5283} \\
\hline HIC & \multicolumn{2}{|c|}{215,0498} & \multicolumn{2}{|c|}{208,9227} \\
\hline
\end{tabular}

Source: own processing

From Table 2, the resulting functional form of the regression model according to formula (1) can be constructed:

FDI inflow $=1800,25+0,4315 * G D P-15,0402 * C P I-40,5311 * T A X+12,0960 * S R$

The most significant factor influencing the inflow of the FDI into the Czech Republic has been proved by a multiple regression analysis of the expenditure on science and research. The analysis has shown that if science and research expenditure rises by CZK 1 billion, the FDI will increase by CZK 12 billion.

Another important determinant of the FDI is the GDP in the Czech Republic. The analysis showed that with an increase in the GDP of CZK 1 billion, there will be an investment inflow of CZK 0.4 billion in the Czech Republic.

On the other hand, the negative impact on the inflow of the FDI was corporation tax. The increase in the income of corporate tax by $1 \%$ led to a decrease in the inflow of the FDI by CZK 40 billion in the monitored period.

The last factor that appears to be significant is the Corruption Perceptions Index. The analysis has shown that if the Index increases by one point (i.e the level of corruption in the Czech Republic decreases), the FDI inflow will be reduced by CZK 15 billion. It is important to emphasize that this indicator appears to be of least importance from the selected ones.

\section{Discussion}

The results of the influence of localization factors on the inflow of foreign investments into the Czech Republic are in line with the conclusions of a number of empirical studies dealing with this issue.

As a minor, the general rate of unemployment, minimum wage, rating, index of economic freedom, and investment incentives appear to be in the resulting regression model. These 
variables were discarded for insignificance. However, it should be borne in mind that these results are tested only for the Czech Republic without comparison with other countries.

Deleting the general rate of unemployment and minimum wages may be due to the diversion of the preferences of investors who currently prefer skilled labor, increasingly demanding and valued. The insignificance of wages in their work agrees with the authors Holland and Pain (1998) who claim that the minimum wage is not decisive for investor decision-making. The results of insignificance of ratings are confirmed by the findings of the study by Bevan and Estrina (2004), who found that investors prefer the business environment to the ability of the government to repay its debts.

Another rejected factor is the Index of Economic Freedom. The reason for rejecting the significance of this variable may be the fact that approximately $90 \%$ of foreign investment in the Czech Republic comes from the EU, which has been trying to harmonize this area in recent years. This suggests that the Index of Economic Freedom is comparable in the Member States and is therefore not one of the major factors for the inflow of the FDI. It can be inferred that the economic freedom index is comparable in the Member States and therefore does not rank among the significant FDI inflows.

The last factor, which appears to be insignificant, is investment incentives. This is confirmed by Demekas et al. (2007) or a study by Blonigena and Pigera (2014). However, the result of investment incentives in the Czech Republic may be distorted due to high multi-collinearity in the GDP, science and research expenditures and minimum wage. Viturka (2000) states that investment incentives are generally viewed positively from the investors' point of view, but only as an aid criterion for investment decision-making. Critical criteria are those that indicate the long-term profit potential of a given area and a low level of risk reducing potential investment efficiency. It should be also taken in account that investment incentives in European countries are very similar, which may explain why they have not been shown to be a significant factor influencing the inflow of FDI into the Czech Republic.

Significant variables include the GDP, science and research expenditures, corruption and corporate income tax. Of these factors, spending on science and research was the most found to be the significant. The reason for this relationship between the FDI and science and research expenditures may be a shift away from cheap labor to qualified personnel. For investors, science and research spending may be valuable information when deciding on the location of their investments. On the basis of these expenditures, investors may assume that the Czech Republic is seeking to support the research of modern production facilities and technology. Also, Benáček (2000) in his publication claims that if the host country wants to support the influx of the FDI, it must support science and research to have a competitive advantage over other countries. According to Blonigena and Pigera (2014), technology innovation influences the inflow of the FDI but is not one of the most crucial factors.

The second most important factor is the GDP variable, which is in line with the conclusions of Bevan and Estrina (2004). The analysis showed that an increase of CZK 0.4 billion in investment in the Czech Republic will increase by CZK 1 billion according to the model specification. The reason for dependence and smaller amounts can be a close link between investment and the GDP. The GDP indicator contains a component of the Gross Fixed Capital (GFC). Investments are also taken into account in this section. GFC shows how domestic and foreign companies are expanding their capacities and hence the growth potential of the entire host economy. The relationship between the GDP and the GFC in 1998-2007 was almost 
identical in the Czech Republic. Both variables react to time " $t$ "in the same way, in the case of the GDP with a short delay. The findings and results of this work confirm this.

Another factor where dependence has been observed was corporate tax. Unlike the previous variables, this indicator has a negative impact on the inflow of investments. The regression analysis has shown that if the corporate tax in the Czech Republic is increased by $1 \%$, the result will be a reduction in the inflow of the FDI by CZK 40 billion, which is in line with the findings of the study by Carstensen and Toubal (2004).

The last factor that appears to be significant is the Corruption Perceptions Index. This conclusion coincides with the conclusions of Bénassy-Quéré, Coupet and Mayer (2007), the results of which confirm that countries with a high level of corruption have up to 7.9 times higher inflows of investment.

\section{Conclusion}

Foreign direct investment, which is an integral part of the economies in the clear majority of countries, brings many positive impacts on the host economy. However, they are not always associated only with positive consequences for the host economy. One of the main negatives of foreign direct investment is, in particular, the displacement of domestic enterprises. It is therefore necessary to consider each investment individually in the specific time and local conditions of the given economy.

Individual countries are interested in positive consequences resulting from inflows of investment. They use various tools to attract investors, and the location factors they naturally have are their own. Each country is unique and unique to them.

In the Czech Republic, geographical location, membership in the EU, NATO, educated population, lower labor costs, attractive investment incentives and stable economic growth can be identified as locating factors for potential investors.

The paper aimed to define the determinants of the FDI inflow into the Czech Republic. The results of the regression model, science and research expenditures, the GDP, corporate tax income and the Corruption Perceptions Index have emerged as significant factors. While spending on science and research or the GDP seem to have a positive effect on FDI, corporate tax and the Corruption Perceptions Index appear to be negative in the results.

The results obtained did not show the impact of investment incentives on the FDI in the Czech Republic. This may be due to the fact that investment incentives in European countries are very similar. For this reason, it is advisable to divert funding from investment incentives to greater support for science and research. On the contrary, it is not recommended to introduce a progressive tax or an increase in the current income tax on the PO, which could lead to a decrease in the inflow of the FDI into the Czech Republic.

\section{References}

[1] BENÁČEK, V. a J. A VÍŠEK, 2000. Přímé zahraniční investice v české ekonomice: praxe, teorie a aplikace. Politická ekonomie, 48(1), 7-24. ISSN 0032-3233.

[2] BÉNASSY-QUÉRÉ, A., M. COUPET and T. MAYER, 2007. Institutional determinants of foreign direct investment. The World Economy, 30(5), 764-782. ISSN 1467-9701.

[3] BEVAN, A. A. and S. ESTRIN, 2004. The determinants of foreign direct investment into European transition economies. Journal of comparative economics, 32(4), 775-787. ISSN 0147-5967. 
[4] BILL, J., D. NĚMEC a M. POSPIŠ, 2009. Gretl - uživatelská příručka. [online]. 2017 [cit. 2017-11-08]. Available from: http://www.thunova.cz/wpcontent/uploads/CZU/Manual_gretl.pdf

[5] BISWAS, R., 2002. Determinants of foreign direct investment. Review of development economics, 6(3), 492-504. ISSN 1467-9361.

[6] BLONIGEN, B. A. and J. PIGER, 2014. Determinants of foreign direct investment. Canadian Journal of Economics/Revue canadienne d'économique, 47(3), 775-812. ISSN 1540-5982.

[7] CARSTENSEN, K. and F. TOUBAL, 2004. Foreign direct investment in Central and Eastern European countries: a dynamic panel analysis. Journal of comparative economics, 32(1), 3-22. ISSN 0147-59.

[8] CZECHINVEST. Tuzemské a přímé zahraniční investice. [online]. 2015 [cit. 2017-1028]. Available from: http://czechinvest.org/data/files/tuzemske-a-prime-zahranicniinvestice-2015-3832-cz.xls

[9] CNB. International relations rating. [online]. 2016 [cit. 2017-11-08]. Available from: www.cnb.cz/en/about_cnb/international_relations/rating/

[10]CNB. Vývoj př́mých zahraničních investic. [online]. 2016 [cit. 2017-11-11]. Available from: https://www.cnb.cz/cs/obecne/rozsirene-vyhledavani.jsp?cnb-search-area=czechversion\&cnb-folder $=\% 2 \mathrm{Fcs} \% 2 \mathrm{~F} \& \mathrm{cnb}$-search-action-block=search\&cnb-searchquery $=\mathrm{p} \% \mathrm{C} 5 \% 99 \% \mathrm{C} 3 \% \mathrm{ADm} \% \mathrm{C} 3 \% \mathrm{~A} 9+$ zahrani\%C4\%8Dn\%C3\%AD+investice

[11]CSO. Hrubý domácí produkt. [online]. 2017 [cit. 2017-11-11].. Available from: https://www.czso.cz/documents/10180/33199373/32020216q403.pdf/a4591368-4d0d$4 \mathrm{f} 72-913 \mathrm{~d}-$

9707b1 efb4db?redirect=https $\% 3 \mathrm{~A} \% 2 \mathrm{~F} \% 2 \mathrm{Fwww} . c z s o . c z \% 2 \mathrm{Fcsu} \% 2 \mathrm{Fczso} \% 2 \mathrm{Fdomov} \% 3$ Fp_p_id\%3D3\%26p_p_lifecycle\%3D0\%26p_p_state\%3Dmaximized $\% 26$ p_p_mode $\% 3$ Dview\%26_3_groupId\%3D0\%26_3_keywords\%3DHRUB\%25C3\%259D\%2520DOM\% 25C3\%2581C\%25C3\%258D\%2520PRODUKT\%26_3_struts_action\%3D\%252Fsearch \%252Fsearch\%26_3_redirect\%3D\%252Fc\%252Fportal\%252Flayout\%253Fp_1_id\%253 D20137706\%2526p_v_1_s_g_id\%253D0

[12]CSO. Míra nezaměstnanosti. [online]. 2016 [cit. 2017-11-11].. Available from: https://www.czso.cz/csu/czso/domov?p_p_id=3\&p_p_lifecycle=0\&p_p_state $=$ maximize $\mathrm{d} \& \mathrm{p} \_\mathrm{p} \_$mode $=$view\&_3_struts_action $=\% 2 \mathrm{Fsearch} \% 2 \mathrm{Fsearch} \& \_3$ _redirect $=\% 2 \mathrm{Fweb} \% 2$ Fczso\%2Fkatalog-produktu

vydavame\&_3_keywords=m\%C3\%ADra+nezam\%C4\%9Bstnanosti+v\%C3\%BDvoj\&_3 _groupId=0

[13]CSO. Vývoj HDP. [online]. 2016 [cit. 2017-11-11]. Available from: https://www.czso.cz/documents/10180/46173149/chmu020117.xlsx/f971babf-241a-4aca$8267-\mathrm{a} 4 \mathrm{aaab} 9 \mathrm{bc} 46 \mathrm{e}$ ?version $=1.0$

[14] CSO. Vývoj nominálního kurzu CZE/EUR. [online]. 2016 [cit. 2017-11-08]. Available from: https://www.czso.cz/documents/10180/32961688/370002160834.xlsx/9764c36a48c447652Fportal\%252Flayout\%253Fp_1_id\%253D20137706\%2526p_v_1_s_g_id\%253D0

[15] CSO. Vývoj výdaje na výzkum a vývoj. [online]. 2016 [cit. 2017-11-10]. Available from: https://www.czso.cz/documents/10180/34193315/21100216p03.pdf/2a7fbea8-300d4 ca8-9f25-204efca9193d? version $=1.0$ 
[16]DEMEKAS, D. G. et al., 2007. Foreign direct investment in European transition economies-The role of policies. Journal of Comparative Economics, 35(2), 369-386. ISSN 0147-59.

[17]DVOŘÁČEK, J., 2005. Strategická analýza vybraných faktorů podnikání v Evropské unii. Praha: Vysoká škola ekonomická, Nakladatelství Oeconomica. ISBN 80-245-08184.

[18]HEBÁK, P., J. HUSTOPECKÝ, E. JAROŠOVÁ a I. MALÁ, 2005. Vicerozměrné statistické metody. Praha: Informatorium. ISBN 807333036.

[19] HOLLAND, D. and N. PAIN, 1998. The diffusion of innovations in Central and Eastern Europe: A study of the determinants and impact of foreign direct investment. London: National Institute of Economic and Social Research.

[20]LIEBSCHER, K., 2007. Foreign direct investment in Europe: a changing landscape. Northampton, MA: E. Elgar. ISBN 1847204872.

[21] TRANSPARENCY INTERNATIONAL (TI). Research CPI overview. [online]. 2016 [cit. 2017-10-28]. Available from: http://www.transparency.org/research/cpi/overview

[22] VALACH, J., 2011. Investiční rozhodování a dlouhodobé financování. Praha: Ekopress. ISBN 978-80-86929-71-2.

[23] VÍŠEK, J. A., 1998. Statistická analýza dat. Praha: Vydavatelství ČVUT. ISBN 8001017354.

[24] VITURKA, M., 2000. Zahraniční investice a strategie regionálního rozvoje. Brno: Masarykova univerzita. ISBN 80-210-2297-3. 